\title{
A Method to Simulate the Migration and Accumulation of Hydrocarbon with Analogue Modeling
}

\author{
Jian Cui $\mathbb{D}^{1},{ }^{1}$ Dong Jia $\left(\mathbb{D},{ }^{1}\right.$ Hongbin Wang, ${ }^{2}$ Hongwei Yin, ${ }^{1}$ Yanjun Wang, ${ }^{2}$ Delong Ma, ${ }^{2}$ \\ Wujun Wu, ${ }^{2}$ Ziyan Jing, ${ }^{2}$ Xiaogen Fan, ${ }^{1}$ Li Shen, ${ }^{3}$ Xiaojun Wu, ${ }^{1}$ Wenqiang Liu, ${ }^{2}$ \\ and Xiulei Yang ${ }^{4}$ \\ ${ }^{1}$ State Key Laboratory for Mineral Deposits Research, School of Earth Sciences and Engineering, Nanjing University, \\ Nanjing 210093, China \\ ${ }^{2}$ Key Laboratory of Reservoir Characterization, Research Institute of Petroleum Exploration and Development-Northwest, \\ PetroChina, Lanzhou 730020, China \\ ${ }^{3}$ School of Civil Engineering and Architecture, Chongqing University of Science and Technology, Chongqing 401331, China \\ ${ }^{4}$ School of Geosciences, East China University of Technology, Nanchang 330013, China
}

Correspondence should be addressed to Dong Jia; djia@nju.edu.cn

Received 29 December 2020; Revised 9 March 2021; Accepted 5 May 2021; Published 22 June 2021

Academic Editor: Yingfang Zhou

Copyright $\odot 2021$ Jian Cui et al. This is an open access article distributed under the Creative Commons Attribution License, which permits unrestricted use, distribution, and reproduction in any medium, provided the original work is properly cited.

\begin{abstract}
Subsurface migration and accumulation of oil and gas have interested researchers for a long time, but these processes may occur over very long geological periods and are difficult to observe directly, so experimental simulations are warranted. In this study, an experimental method was developed to model hydrocarbon migration in the subsurface structure. Oil migration was simulated in a sandbox model, and industrial CT scanning was used to observe both the internal geometry of the model and the oil migration pathways. In the sandbox model, a NaI solution was used to simulate water, white oil was used to simulate hydrocarbon, and fine quartz sand, glass bead, silica powder, and brown corundum were chosen to represent brittle crust, based on suitable material parameters. A NaI-saturated layered sandbox model was constructed with an along-strike basal discontinuity, which during compression allowed a simple anticline with doubly verging reverse faults to form. Oil was then released continuously at a low rate from an orifice under one limb of the anticline. Initially, the oil migrated vertically through the fault zone until it reached the top of the fault zone; it then migrated laterally along the core of the anticline, saturating a model reservoir by buoyancy and capillary force. This experimental analog helps to explain hydrocarbon migration and accumulation within the Anjihai and Santai anticlines in northwest China.
\end{abstract}

\section{Introduction}

Hydrocarbon migration from source rocks through water saturated carrier beds, faults, and unconformities to reservoir rocks is a complex subsurface process $[1,2]$. Although migration is important to hydrocarbon exploration, our understanding of the process has been limited by the long geological time involved and by the inability to observe it directly [3-6].

Physical experiments can be effective methods to study the process of oil migration in porous media (e.g., $[7,8]$ ). Early experiments were limited by observation techniques; in most published works, researchers could only observe oil migration pathways along the edges of the models $[9,10]$. With recent developments in science and technology, new technical methods have been used to observe the oil migration process, including migration pathways and oil saturation: (a) ultrasonic techniques [11], (b) magnetic resonance imaging (MRI; [12-14]), and (c) X-ray computed tomography (CT; [15-18]).

Analogue modeling is an effective method to study the mechanics, kinematics, and dynamics of geologic structures and can help us better understand geological processes in space and time [19-24]. Among recent sandbox studies, 
new technical approaches are being used to analyze the sand models, such as laser scanning $[25,26]$, strain gauges $[27,28]$, centrifuges $[29,30]$, particle imaging velocimetry (PIV; [24, $31,32]$ ), and X-ray computed tomography (CT; [33-35]).

The previous physical experiments to study oil migration were commonly focused on oil migration in reservoirs, and did not combine oil migration with structure. Therefore, in order to study oil migration within a subsurface structure, this paper innovatively combined oil migration with structural analogue modeling.

Prior research has shown that although ultrasonic techniques and magnetic resonance imaging allow observation of migration pathways in porous media models, neither technique allows observation of the distribution of different granular materials and the location of fault zones through density differences. In this study, we selected an industrial CT to visualize both the internal geometry of the sandbox model and oil migration and accumulation.

Colletta et al. [36] have shown that CT is a nondestructive technique to analyze the internal kinematic evolution of a physical model. The CT technique is fundamentally based on the distinct attenuation of X-rays through different materials as a function of material density, effective atomic number, and thickness [37]. As the experimental materials have distinct attenuation values, their boundaries can be visualized, and a stratified model can be obtained.

In this study, a simulation experiment was carried out and the suitable fluid and granular materials were tested and proposed. The sandbox model experiment was focused on oil migration pathways and on comparing the model results with the hydrocarbon accumulation profile. The model results showed that the experiment simulated the process of oil migration and accumulation in the underground structure well, especially under the influence of fault zones. The results of the simulation experiment provide an analogue to better understand the controls on oil migration and accumulation in the subsurface fault zones of the Anjihai and Santai anticlines in northwest China.

\section{Experimental Approach}

2.1. Experimental Materials. To simulate underground hydrocarbon migration, the sandbox model was saturated, but instead of water and in order to increase the density difference with oil [16], a NaI solution was used; this resulted in more distinct $\mathrm{X}$-ray attenuation values that improved the CT visualization of fluid boundaries. The $\mathrm{NaI}$ solution was a 10:17 mixture of $\mathrm{NaI}$ and water by weight, with a density of $\sim 1.380 \mathrm{~g} / \mathrm{cm}^{3}$, viscosity of $1.348 \mathrm{mPa}$, and surface tension of $67.0 \mathrm{mN} / \mathrm{m}$. The oil used for the experiment was white oil, with a density of $\sim 0.824 \mathrm{~g} / \mathrm{cm}^{3}$, viscosity of $6.266 \mathrm{mPa}$, and surface tension of $27.8 \mathrm{mN} / \mathrm{m}$. All parameters were measured at $20^{\circ} \mathrm{C}$.

In the sandbox model, the reservoir rock was represented by glass bead and the cap rock by pure silica powder. A layer of fine quartz sand was put on the bottom of the sandbox so that the oil migration pathway would not be affected by the different wettability and pore structure of the sandbox bottom boundary compared with the porous medium $[11,14]$.

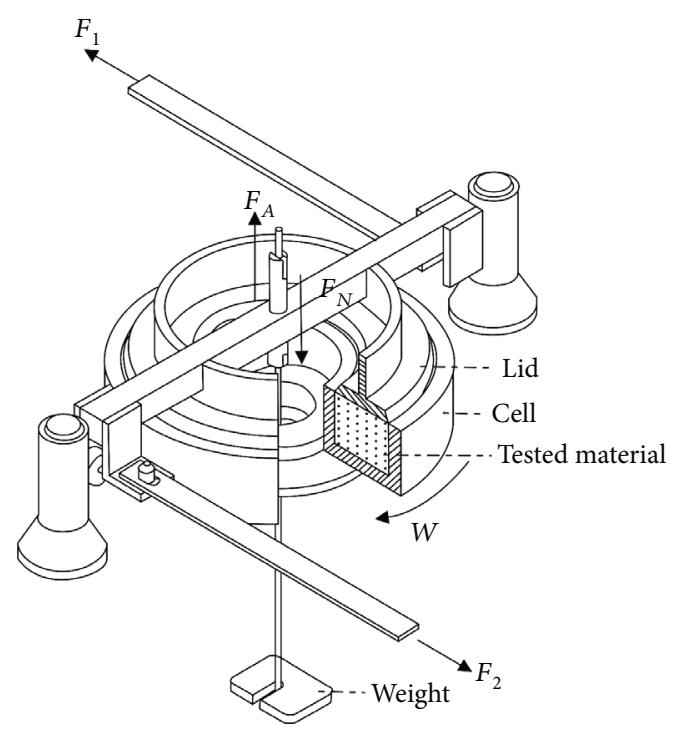

FIGURE 1: Sketch of the ring shear tester. Granular material is sifted into an annular cell, and a variable vertical load $F_{N}$ is applied through an annular lid which can be adjusted with weights. The cell rotates with a constant angular velocity while the lid is kept firm. The shear force $\left(\mathrm{F}_{1}+\mathrm{F}_{2}\right)$ is measured during the rotation of the cell (modified from [39]).

A layer of brown corundum was placed on the silica powder to keep it stable during deformation and oil injection, as the silica powder was unstable when settled in the $\mathrm{NaI}$ solution. When the glass bead, silica powder, and fine quartz sand were saturated with $\mathrm{NaI}$ solution, their attenuation differences were diminished and their boundaries became unclear. Therefore, thin layers of brown corundum were placed between every two layers of the materials as marker layers, so that structural features would be clearly displayed.

A natural sand was used whereas the glass bead, silica powder, and brown corundum were artificial products. From information provided by the suppliers, the glass bead has a grain size of $\sim 550 \mu \mathrm{m}$, the silica powder has a grain size of $\sim 18 \mu \mathrm{m}$, the brown corundum has a grain size of $\sim 150 \mu \mathrm{m}$, and the quartz sand has a grain size range of $120-150 \mu \mathrm{m}$.

The four granular frictional materials commonly used to simulate brittle deformation in previous analogue studies, and they fail obey the Mohr-Coulomb envelope [38-40]. The linear Mohr-Coulomb envelope can be described by the following equation:

$$
\tau=\mu \times \sigma_{n}+C
$$

where $C$ is cohesion and $\mu$ is the coefficient of internal friction defined by $\mu=\tan \phi$, where $\phi$ is the angle of internal friction $[41,42]$. In order to obtain the cohesion and the angle of internal friction for the four granular frictional materials, a ring shear tester was employed (Figure 1). Material was sifted into an annular cell, and a variable vertical load $F_{N}$ was then applied by a lid fitting into the cell. The cell rotated with a constant angular velocity while the lid is kept firm. During rotation, a horizontal shear zone developed in the granular material at the transition between the fixed lid and the 
(1)

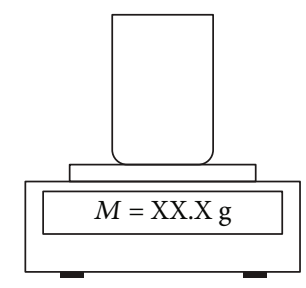

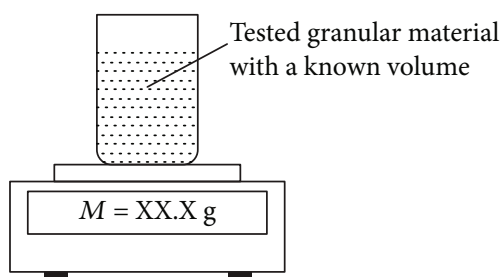

(2)

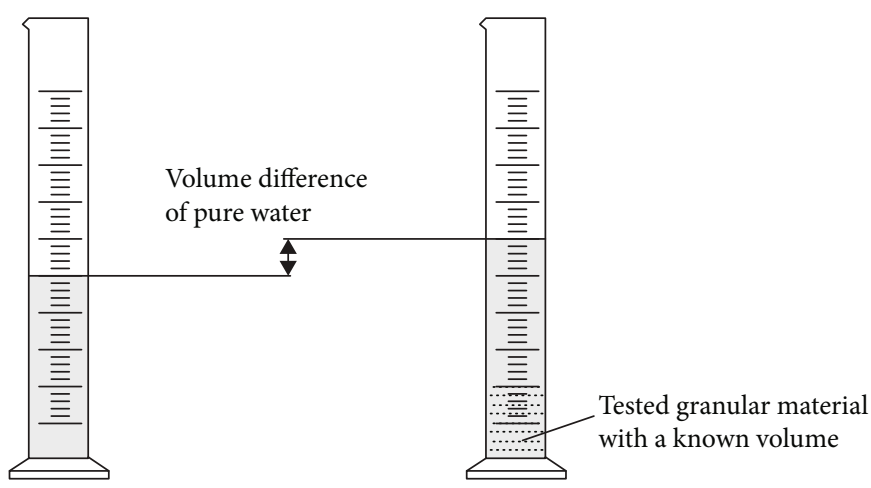

FIgURE 2: (1) The bulk density of a granular material was measured by sifting the granular material into the measurement container from a consistent height and weighing the known volume of material on an electronic balance. (2) The porosity of the granular material was determined by pouring a known volume of a granular material into a measuring cylinder containing a certain amount of pure water and measuring the volume of the empty space and the material particle. The porosity of the granular material is calculated from the known volume of the empty space divided by the total volume of the material.

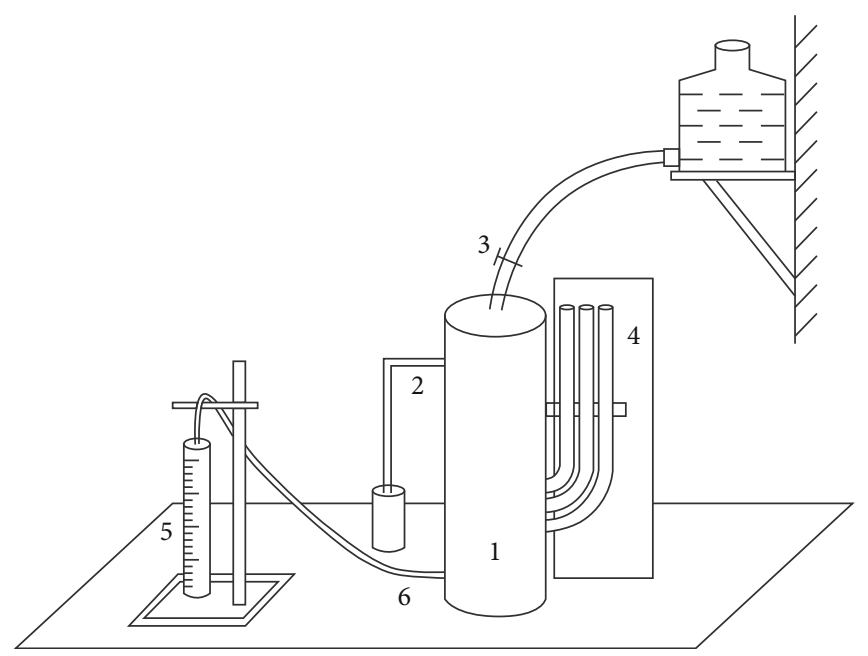

FIGURE 3: Schematic diagram of the permeameter setup, showing the metal cylinder (1), overflow pipe (2), water supply pipe (3), pressure measuring pipe (4), measuring cylinder (5), and drain pipe (6). In the experiment, the length $L$ (space between the pressure measuring pipes) and the cross-sectional area $S$ of the sample packing in the metal cylinder were measured and remained unchanged. Water was injected into the metal cylinder through the water supply pipe, with the overflow pipe ensuring that the water level inside the cylinder remained unchanged. The fluid pressure $(\Delta P)$ was obtained from the pressure measuring pipe, and the seepage flow $(Q)$ was obtained from the measuring cylinder connected with the drain pipe. From equation (2), an absolute permeability of the granular material was obtained.

rotating cell, and the shear force $\left(\mathrm{F}_{1}+\mathrm{F}_{2}\right)$ was recorded. Therefore, the cohesion and the angle of internal friction through variable vertical load $F_{N}$ could be measured [39]. For a vertical load $F_{N}$ of $\sim 1300-1500 \mathrm{~Pa}$, the values of cohesion and the angle of internal friction for the quartz sand are
$69 \mathrm{~Pa}$ and $35.2^{\circ}$, for the glass bead are $23.2 \mathrm{~Pa}$ and $27.4^{\circ}$, for the silica powder are $354.7 \mathrm{~Pa}$ and $38.8^{\circ}$, and for the brown corundum are $56.1 \mathrm{~Pa}$ and $37.2^{\circ}$.

The bulk density is calculated by measuring the mass of a known volume of material with an electronic balance. To be 
TABLE 1: Physical properties of granular materials: grain size $(D)$, cohesion $(C)$, angle of internal friction $(\phi)$, bulk density $\left(\rho_{\mathrm{b}}\right)$, porosity $(\theta)$, and permeability $(K)$.

\begin{tabular}{lcccccc}
\hline Materials & $\begin{array}{c}D \\
(\mu \mathrm{m})\end{array}$ & $\begin{array}{c}C \\
(\mathrm{pa})\end{array}$ & $\begin{array}{c}\phi \\
\left(^{\circ}\right)\end{array}$ & $\begin{array}{c}\rho_{\mathrm{b}} \\
\left(\mathrm{kg} / \mathrm{m}^{3}\right)\end{array}$ & $\begin{array}{c}\theta \\
(\%)\end{array}$ \\
\hline Quartz sand & $120-150$ & 69 & 35.2 & 1390 & 38.0 & $1.8 \times 10^{-11}$ \\
Glass bead & 550 & 23.2 & 27.4 & 1490 & 36.5 & $2.9 \times 10^{-10}$ \\
Silica powder & 18 & 354.7 & 38.8 & 1400 & 32.5 & $3.0 \times 10^{-13}$ \\
Brown corundum & 150 & 56.1 & 37.2 & 1770 & 42.7 & $2.4 \times 10^{-11}$ \\
\hline
\end{tabular}

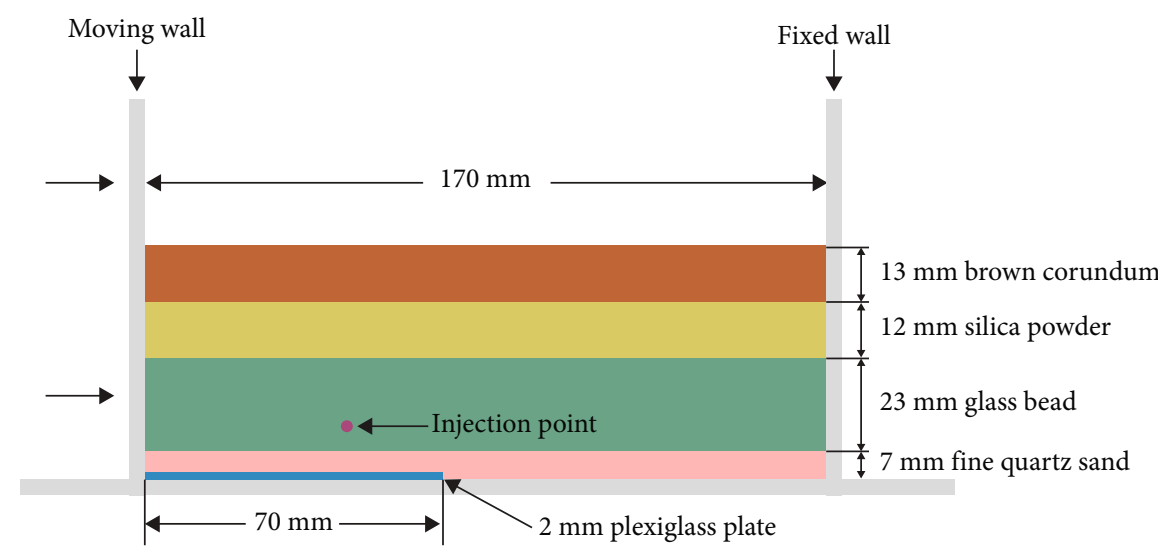

FIGURE 4: Schematic diagram of the initial experimental setup for the layered sandbox model.

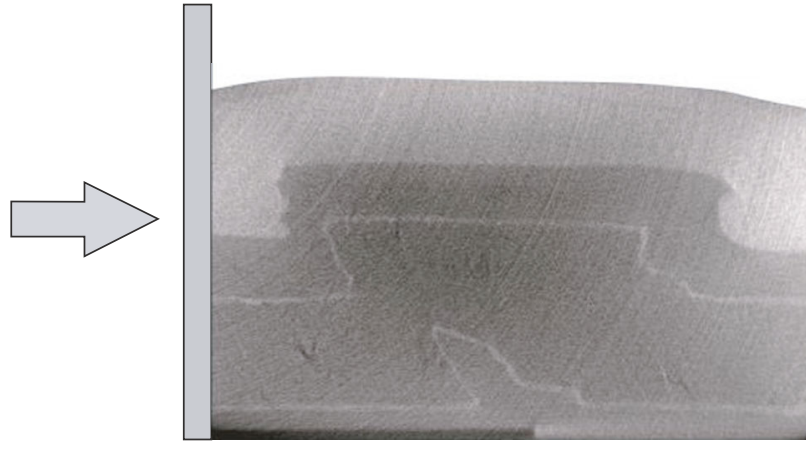

(a)

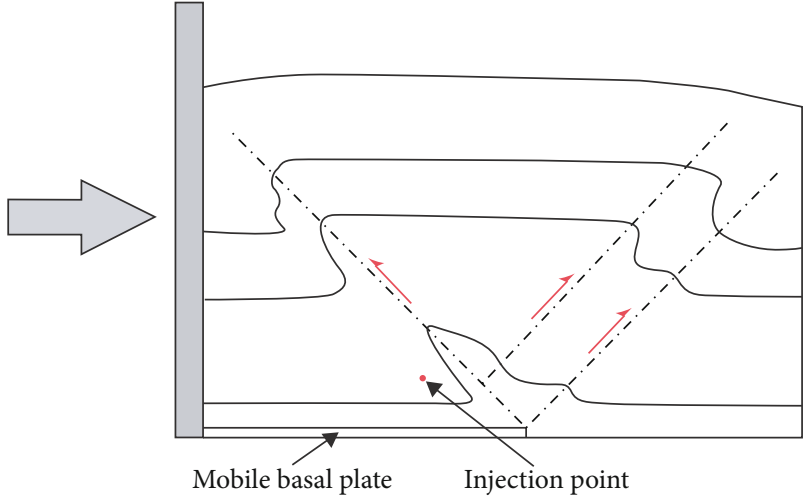

(b)

Figure 5: CT image (a) and line drawing (b) of the experimental result.

consistent with the stacking pattern in the analogue model, the granular materials were sifted into the measurement container from a height consistent with the analogue experiment. The porosity was determined using a measuring cylinder. A known volume of a material was poured into a measuring cylinder containing a certain amount of pure water, and the volume of the empty space and material particles were obtained through the volume difference of the pure water (Figure 2). The porosity was then calculated from the known volume of the empty space divided by the total volume of the material. The approximate values of bulk density and porosity for the quartz sand are $1390 \mathrm{~kg} / \mathrm{m}^{3}$ and $38.0 \%$, for the glass bead are $1490 \mathrm{~kg} / \mathrm{m}^{3}$ and $36.5 \%$, for the silica powder are $1400 \mathrm{~kg} / \mathrm{m}^{3}$ and $32.5 \%$, and for the brown corundum are $1770 \mathrm{~kg} / \mathrm{m}^{3}$ and $42.7 \%$.

Permeability is defined as the ability of a porous material to allow fluids to pass through it at a given pressure difference. We measured the permeability for a porous material using a permeameter (Figure 3), through Darcy's law:

$$
\mathrm{Q} / S=(K / \eta) *(\Delta \mathrm{P} / L)
$$

where $Q / S$ is the Darcy velocity, $\eta$ is the dynamic viscosity of the fluid, $L$ is the length of the bead packing, $\Delta P$ is the pressure drop of the bead packing with the length of $L$, and $K$ is the absolute permeability. In the experiments, the length $L$ 


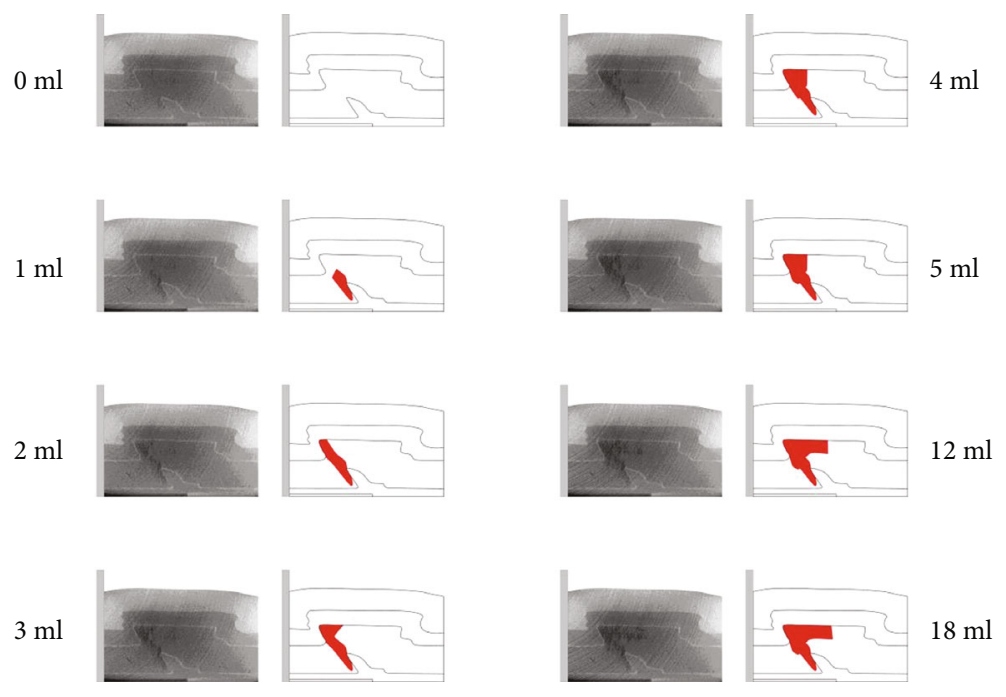

FIgURE 6: CT images and line drawings of the oil migration process in the model for increasing amounts of injected oil (ml). The darkest areas in the CT images and the red areas in the line drawings are the areas saturated with oil.

(space between the pressure measuring pipes) and the crosssectional area $S$ of the sample packing in the metal cylinder were measured and remained unchanged. The overflow pipe on the metal cylinder ensured that the water level inside the cylinder remained unchanged. Water was injected at a certain rate into the metal cylinder through the water supply pipe at the top. The fluid pressure $\Delta P$ was obtained from the pressure measuring pipes, and the seepage flow $Q$ was obtained from the measuring cylinder connected with the drain pipe. Pure water with a dynamic viscosity of $\eta=10^{-3}$ Pa.s was used as the incompressible fluid. Absolute permeability was obtained from equation (2) for the quartz sand $\left(\sim 1.8 \times 10^{-11} \mathrm{~m}^{2}\right)$, glass bead $\left(\sim 2.9 \times 10^{-10} \mathrm{~m}^{2}\right)$, and brown corundum $\left(\sim 2.4 \times 10^{-11} \mathrm{~m}^{2}\right)$. The absolute permeability for the silica powder $\left(\sim 3.0 \times 10^{-13} \mathrm{~m}^{2}\right)$ was obtained from a professional company.

For comparison, all the granular material properties are listed in Table 1.

2.2. Experimental Setup. To compare the model results with the geological sections and study the migration and accumulation in the anticlines, a simulation experiment was carried out. An along-strike basal velocity discontinuity was incorporated to allow for the formation of noncylindrical structure in the center of the experiment [43].

The model was run in a plexiglass rectangular box with a horizontal rigid basement, two stationary sidewalls, one fixed wall, and one moving wall. The basal velocity discontinuity at the bottom of the sandbox was created by a plexiglass sheet, measuring $70 \times 200 \times 2 \mathrm{~mm}$, which was fixed to the moving wall and was able to slide over the basement during shortening. A motor-driven piston was connected to the moving wall to move it forward. The sandbox had a fixed width of $200 \mathrm{~mm}$, depth of $120 \mathrm{~mm}$, and an initial length of $170 \mathrm{~mm}$ parallel to the axis of compression. The sandbox was cleaned with an alcoholic solution prior to layering in the granular materials.

The NaI solution was poured into the box before layering to ensure there was no air in the model. The sand body,

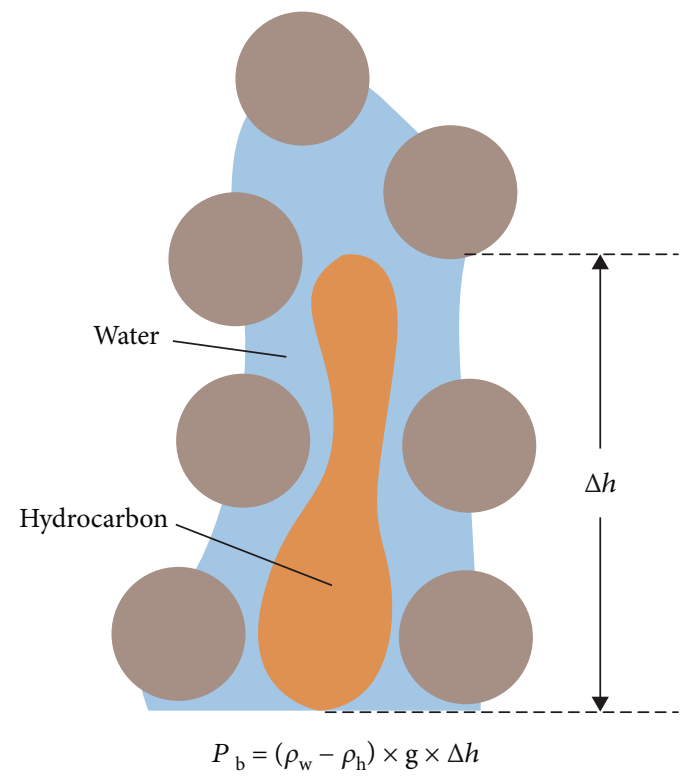

FIGURE 7: Schematic diagram for buoyancy as a driving force in hydrocarbon migration (modified from [51]).

which was $45 \mathrm{~mm}$ thick, had four layers consisting of (from the base up) the following: fine quartz sand $7 \mathrm{~mm}$ thick, glass bead $23 \mathrm{~mm}$ thick, silica powder $12 \mathrm{~mm}$ thick, and brown corundum $13 \mathrm{~mm}$ thick (Figure 4 ). The shortening rate was $0.0005 \mathrm{~mm} / \mathrm{s}$, and the shortening length was $40 \mathrm{~mm}$. After the deformation, oil was injected into the sand body by pumping through an orifice under one limb of the anticline at a constant rate and set distance from the bottom. During the injection of the oil, successive internal cross-section images were obtained near the injection orifice by industrial CT.

Due to the low speed of the current industrial CT in single slice scanning mode, and the fast oil migration process in the model, only a single slice of the model could be scanned at each stage during the experiment. Experimental results 


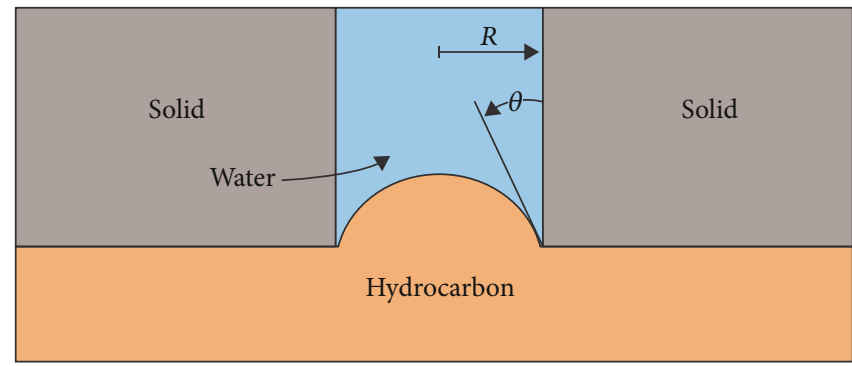

$P_{\mathrm{c}}=2 \times \gamma \times \cos \theta / R$

FIGURE 8: Schematic diagram to illustrate capillary force as a restricting force in hydrocarbon migration (modified from [51]).

could be improved in the future as industrial CT becomes more efficient and increased data volumes can be scanned.

\section{Experimental Results}

The model deformation resulted in a doubly verging thrust system and a wide uniform anticline, with thrusts nucleated at the leading edge of the basal plate in the center of the experiment (Figure 5). After the deformation, oil was injected at a relatively low rate of about $0.02 \mathrm{ml} / \mathrm{min}$ to prevent the injection pressure from affecting the migration path of the oil. The location of the oil injection orifice is shown in Figure 5.

The result shows that the fault planes forming in granular material correspond to zones of dilation and act as conduits that oil migrates preferentially within the fault zone (Figure 6). In the experiment, the fault zone had an effect on the oil migration pathway since the beginning of oil injection because the oil injection orifice was just below the fault zone. After $1 \mathrm{ml}$ of oil was injected, because of the influence of the fault zone, oil migrated vertically up to the middle of the fault zone. After 2 to $3 \mathrm{ml}$ of injection, oil continued to migrate vertically within the fault zone and migrate up to the top. After 4 to $5 \mathrm{ml}$ of injection, the migration path in the fault zone widened. Finally, after 12 to $18 \mathrm{ml}$ of injection, the oil migrated laterally along the core of the anticline and began to pool.

On the whole, the fault zone controlled the pathway of oil migration in the modeling experiment. The oil migrated vertically to the top through the fault zone and then migrated laterally and began to pool.

\section{Discussion}

Faults play an important role in hydrocarbon accumulation, affecting oil and gas reservoirs through all phases of exploration and development [44-46]. Faults can act as conduits or barriers, depending on whether they are active or inactive during hydrocarbon migration [47-50]. The experimental result shows that the fault zone has a great influence on the oil migration pathway and acts as conduits in sandbox modeling experiments (Figure 6).

For hydrocarbon migration under hydrostatic conditions, the main driving force is buoyancy, which is a function of the density difference between the hydrocarbon and the pore water and the height of the hydrocarbon column:

$$
P_{\mathrm{b}}=\left(\rho_{\mathrm{w}}-\rho_{\mathrm{h}}\right) \times g \times \Delta h,
$$

where $P_{\mathrm{b}}$ is the buoyant force, $\rho_{\mathrm{w}}$ and $\rho_{\mathrm{h}}$ are the respective subsurface densities of water and hydrocarbon, $g$ is the acceleration due to gravity, and $\Delta h$ is the height of oil column (Figure 7).

The main restricting force is capillary force, which is a function of the radius of the pore throat, the interfacial surface tension between the water and the hydrocarbon, and the wettability of the hydrocarbon-water rock system:

$$
P_{\mathrm{c}}=2 \times \gamma \times \cos \theta / R,
$$

where $P_{\mathrm{c}}$ is the capillary force, $\gamma$ is the interfacial tension between hydrocarbon and water, $\theta$ is the wettability expressed as the contact angle of the hydrocarbon-water interface against the rock surface, and $R$ is the effective radius of the pore (Figure 8). Therefore, capillary force is inversely proportional to the pore size [51]. In the schematic diagrams for buoyancy (Figure 7) and capillary force (Figure 8), the pore structures are idealized; actual pore structures may be more complex, such as in the Middle Jurassic Xishanyao Shale Formation of the Southern Junggar Basin [52].

In sandbox modeling experiments, the normal arrangement of grains is disturbed within the fault zones, causing the fault zones to become zones of dilation and the bulk density decreased within the fault zones. This results in a decrease of X-ray attenuation in the fault zones, allowing the development of the faults to be observed [53-55]. For oil migration in the sandbox modeling experiments, the decrease of the bulk density within the fault zones causes the pore size within the fault zones to be greater than without. Therefore, the capillary force which is the main restricting force for oil migration is smaller within the fault zones than without and oil preferentially migrates within the fault zones. This is consistent with what was observed in this study that the faults serve as flow paths for the oil.

The results of the simulation experiment provide an analogue to help understand hydrocarbon migration and accumulation in the Anjihai anticline (Figure 9) and the Santai anticline (Figure 10) in northwest China, which are similar 


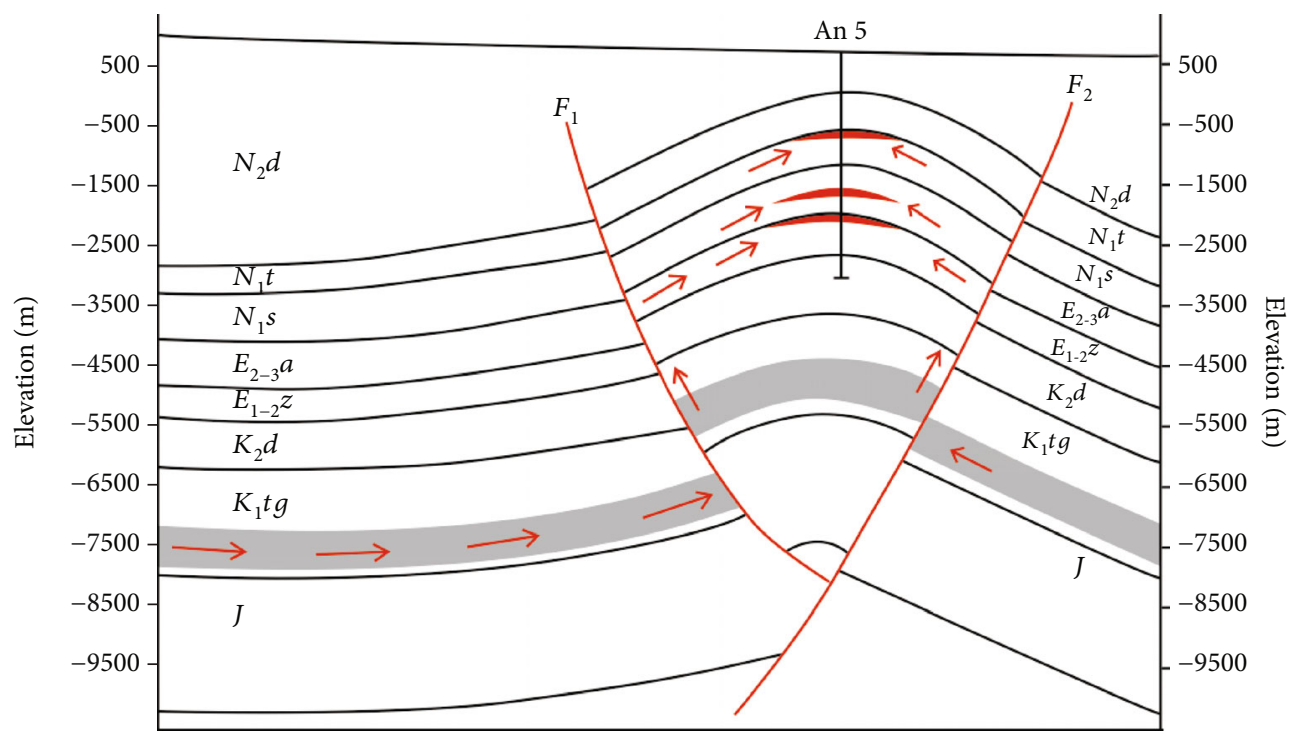

$\square$ Fault

$\square$ Hydrocarbon pool

$\square$ Source rock

FIgURE 9: Cross-section of the Anjihai anticline depicting the hydrocarbon migration and accumulation pattern and the location of the An5 well. F1: South Anjihai fault; F2: North Anjihai fault.

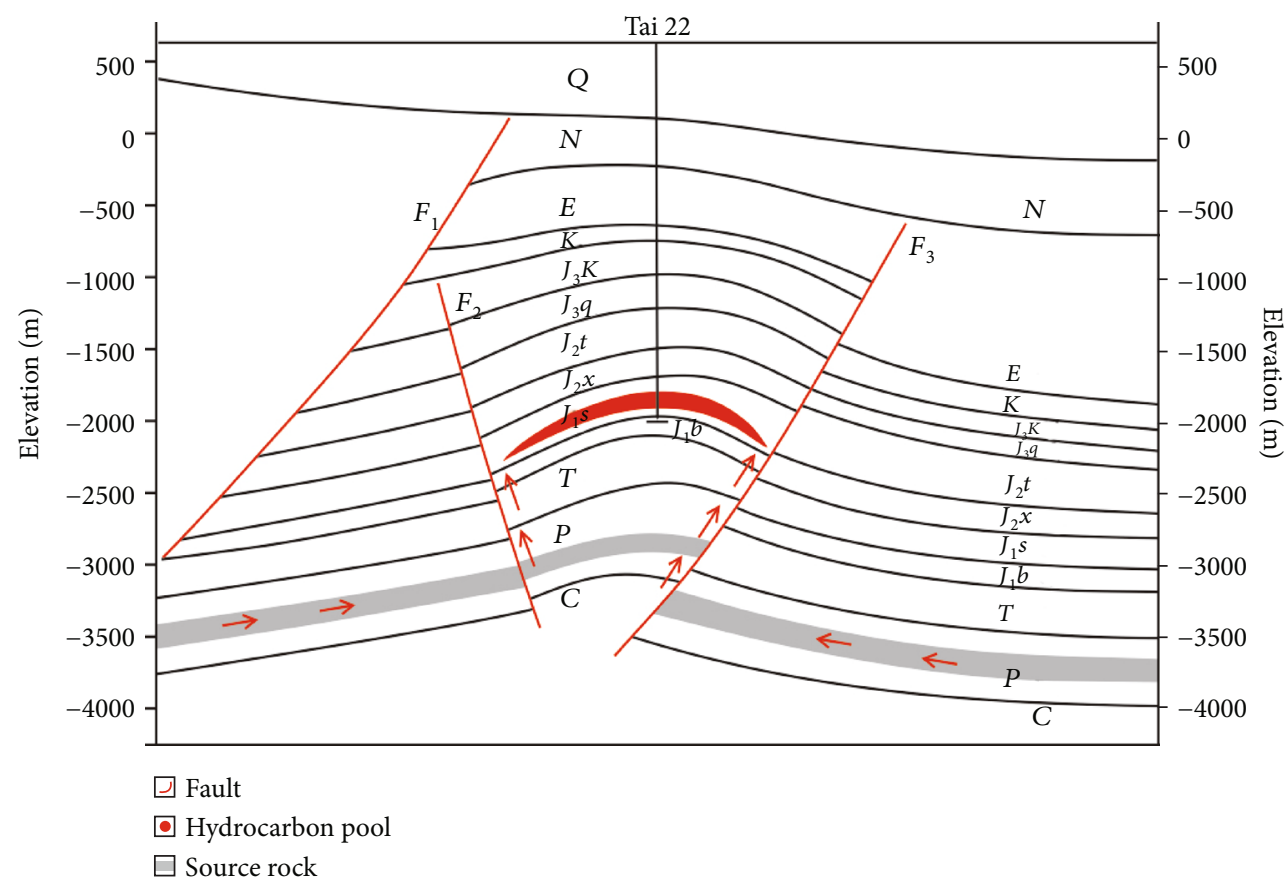

FIGURE 10: Cross-section of the Santai anticline showing the hydrocarbon migration and accumulation pattern of the Santai anticline and the location of the Tai 22 well. F1: Fukang fault; F2: South Ganhezi fault; F3: North Ganhezi fault.

to the structure formed in the sandbox model. The structures and the well information of the two anticlines have been studied by researchers from the Research Institute of Petroleum Exploration and Development-Northwest, PetroChina.

The Anjihai anticline, a typical fault-related fold located in the Northern Tianshan fold-thrust belt, is controlled by the North Anjihai and the South Anjihai faults. Fine- grained Cretaceous source rocks within the oil generation window are developed within the Anjihai anticline, and a hydrocarbon pool was discovered in Cenozoic clastic reservoirs drilled by the An 5 well. The hydrocarbon pool in $\mathrm{N}_{1} s$ Formation generated in a $6 \mathrm{~m}$ thick muddy siltstone. Its porosity is $14.60-17.70 \%$, and permeability is $0.97-6.14 \times 10^{-3} \mu \mathrm{m}^{2}$. The vertical and horizontal migration distances are 4.4 and 
$3.9 \mathrm{~km}$, respectively. The hydrocarbon pool in $\mathrm{E}_{2-3} a$ Formation generated in a $6 \mathrm{~m}$ thick siltstone. Its porosity is 6.30 $6.48 \%$, and permeability is $0.24-0.56 \times 10^{-3} \mu \mathrm{m}^{2}$. The vertical and horizontal migration distances are 3.4 and $3.8 \mathrm{~km}$, respectively. The hydrocarbon pool in $\mathrm{E}_{1-2} z$ Formation generated in a $4 \mathrm{~m}$ thick siltstone. Its porosity is $16.30-18.30 \%$, and permeability is $5.16-8.13 \times 10^{-3} \mu \mathrm{m}^{2}$. The vertical and horizontal migration distances are 3.0 and $3.5 \mathrm{~km}$, respectively.

Santai anticline is located in the footwall of Fukang fault, between the North Ganhezi and the South Ganhezi faults. The Permian Lucaogou Formation mudstones, the most important source rocks in Junggar Basin, are developed in this area at peak hydrocarbon generation maturity. Well Tai 22 was drilled through the Lower Jurassic clastic reservoir in the anticline, where a hydrocarbon pool was discovered. The hydrocarbon pool in $\mathrm{J}_{1} s$ Formation generated in an $8 \mathrm{~m}$ thick muddy siltstone and fine sandstone. Its porosity is $9.43-23.30 \%$. The vertical and horizontal migration distances are 2.5 and $2.9 \mathrm{~km}$, respectively.

Comparing the modeling result with the two anticlines, it is clear that the faults acted as conduits, connecting the deeper source rocks with the shallow reservoirs. In the Anjihai anticline, the hydrocarbon generated in the Cretaceous source rock migrated laterally and then vertically to the Cenozoic reservoir through the fault system, finally accumulating in the core of the anticline. In the Santai anticline, the North Ganhezi and the South Ganhezi faults acted as conduits, connecting the deeper Permian source rocks with the shallow Jurassic reservoir. The hydrocarbon generated in the Permian source rocks migrated laterally and then vertically to the Jurassic reservoir through the fault system, finally accumulating in the core of anticline.

\section{Conclusions}

In this paper, an experimental method was developed to simulate hydrocarbon migration in the subsurface structure. The approach combined the initial selection of sandbox materials, testing their parameters, building the sandbox model, and injecting oil during sandbox deformation. Industrial CT scanning was used to track the progress of the analogue modeling experiment. A NaI solution and white oil were used as the fluid materials, and fine quartz sand, glass bead, silica powder, and brown corundum as the granular materials.

The deformed state sandbox model consisted of a broad anticlinal structure with a doubly verging thrust system. In the simulation experiment, oil was injected at a relatively low rate under one limb of the anticline, at a set distance above the bottom of the sandbox model. The experimental results showed that faults served as flow paths for the oil. Initially, oil migrated vertically to the top of the fault zone, and then laterally along the core of the anticline, pooling at the crest.

The Anjihai and Santai anticlines are similar to the structure formed in the analogue model. Comparing the model results with the subsurface structures provides an explanation of how oil migrated and accumulated in the two anticlines. In both anticlines, faults acted as conduits, connecting the deeper source rocks with the shallow reservoirs.
The hydrocarbon generated in the source rocks migrated laterally, and then vertically to the reservoirs through the fault system, finally accumulating in the core of the anticlines.

\section{Data Availability}

The datasets used in the present study are available from the corresponding authors upon reasonable request.

\section{Conflicts of Interest}

The authors declare that they have no conflicts of interest.

\section{Acknowledgments}

We thank the Research Institute of Petroleum Exploration and Development-Northwest, PetroChina, for their help in the experiments. This study was funded by the National Natural Science Foundation of China (Grant No. 41927802) and National S\&T Major Project of China (2017ZX005008001).

\section{References}

[1] S. Xu, F. Hao, C. Xu et al., "Hydrocarbon migration and accumulation in the northwestern Bozhong subbasin, Bohai Bay Basin, China," Journal of Petroleum Science and Engineering, vol. 172, pp. 477-488, 2019.

[2] J. Zhang, J. Cao, Y. Wang, G. Hu, N. Zhou, and T. Shi, "Origin of giant vein-type bitumen deposits in the northwestern Junggar Basin, NW China: implications for fault-controlled hydrocarbon accumulation," Journal of Asian Earth Sciences, vol. 179, pp. 287-299, 2019.

[3] M. K. Hubbert, "Entrapment of petroleum under hydrodynamic conditions," AAPG Bulletin, vol. 37, pp. 1954-2026, 1953.

[4] P. Ungerer, J. Burrus, B. Doligez, P. Y. Chenet, and F. Bessis, "Basin evaluation by integrated two-dimensional modeling of heat transfer, fluid flow, hydrocarbon generation, and migration," AAPG Bulletin, vol. 74, pp. 309-335, 1990.

[5] X. Luo, "Simulation and characterization of pathway heterogeneity of secondary hydrocarbon migration," AAPG Bulletin, vol. 95, pp. 881-898, 2011.

[6] B. Liu, J. Sun, Y. Zhang et al., "Reservoir space and enrichment model of shale oil in the first member of Cretaceous Qingshankou Formation in the Changling sag, southern Songliao Basin, NE China," Petroleum Exploration and Development, vol. 48, pp. 1-16, 2021.

[7] T. Tokunaga, K. Mogi, O. Matsubara, H. Tosaka, and K. Kojima, "Buoyancy and interfacial force effects on twophase displacement patterns: an experimental study," AAPG Bulletin, vol. 84, pp. 65-74, 2000.

[8] R. Toussaint, G. Løvoll, Y. Méheust, K. J. Måløy, and J. Schmittbuhl, "Influence of pore-scale disorder on viscous fingering during drainage," Europhysics Letters (EPL), vol. 71, no. 4, pp. 583-589, 2005.

[9] L. Catalan, F. Xiaowen, I. Chatzis, and F. A. Dullien, "An experimental study of secondary oil migration," AAPG Bulletin, vol. 76, pp. 638-650, 1992.

[10] V. V. Frette, J. Feder, T. Jossang, and P. Meakin, "Buoyancydriven fluid migration in porous media," Physical Review Letters, vol. 68, no. 21, pp. 3164-3167, 1992. 
[11] M. M. Thomas and J. A. Clouse, "Scaled physical model of secondary oil migration," AAPG Bulletin, vol. 79, pp. 19-28, 1995.

[12] I. Koptyung, A. Matveev, and S. Altobelli, "NMR studies of hydrocarbon gas flow and dispersion," Applied Magnetic Resonance, vol. 22, no. 2, p. 187, 2002.

[13] X. Luo, F. Zhang, S. Miao et al., "Experimental verification of oil saturation and losses during secondary migration," Journal of Petroleum Geology, vol. 27, no. 3, pp. 241-251, 2004.

[14] J. Yan, X. Luo, W. Wang et al., "An experimental study of secondary oil migration in a three-dimensional tilted porous medium," AAPG Bulletin, vol. 96, no. 5, pp. 773-788, 2012.

[15] J. Hou, Z. Li, S. Zhang, X. Cao, Q. Du, and X. Song, "Computerized tomography study of the microscopic flow mechanism of polymer flooding," Transport in Porous Media, vol. 79, no. 3, pp. 407-418, 2009.

[16] Z. T. Karpyn, M. Piri, and G. Singh, "Experimental investigation of trapped oil clusters in a water-wet bead pack using Xray microtomography," Water Resources Research, vol. 46, no. $4,2010$.

[17] R. S. Seright, M. Prodanovic, and W. B. Lindquist, "X-ray computed microtomography studies of fluid partitioning in drainage and imbibition before and after gel placement: disproportionate permeability reduction," SPE Journal, vol. 11, no. 2, pp. 159170, 2006.

[18] S. Youssef, H. Deschamps, J. Dautriat et al., " $4 \mathrm{D}$ imaging of fluid flow dynamics in natural porous media with ultra-fast $\mathrm{X}$-ray microtomography," in International Symposium of the SCA, Napa Valley, California, 2013.

[19] S. J. H. Buiter, "A review of brittle compressional wedge models," Tectonophysics, vol. 530-531, pp. 1-17, 2012.

[20] C. Del Ventisette, M. Bonini, D. Maestrelli, F. Sani, E. Iavarone, and D. Montanari, "3D-thrust fault pattern control on negative inversion: an analogue modelling perspective on Central Italy," Journal of Structural Geology, vol. 143, p. 104254, 2021.

[21] T. P. Dooley and G. Schreurs, "Analogue modelling of intraplate strike-slip tectonics: a review and new experimental results," Tectonophysics, vol. 574-575, pp. 1-71, 2012.

[22] F. Graveleau, J. Malavieille, and S. Dominguez, "Experimental modelling of orogenic wedges: a review," Tectonophysics, vol. 538-540, pp. 1-66, 2012.

[23] H. Koyi, "Analogue modelling: from a qualitative to a quantitative technique-a historical outline," Journal of Petroleum Geology, vol. 20, no. 2, pp. 223-238, 1997.

[24] D. P. Yan, Y. B. Xu, Z. B. Dong, L. Qiu, S. Zhang, and M. Wells, "Fault-related fold styles and progressions in fold-thrust belts: insights from sandbox modeling," Journal of Geophysical Research: Solid Earth, vol. 121, no. 3, pp. 2087-2111, 2016.

[25] J. Li and S. Mitra, "Geometry and evolution of fold-thrust structures at the boundaries between frictional and ductile detachments," Marine and Petroleum Geology, vol. 85, pp. 16-34, 2017.

[26] F. Nilforoushan, H. A. Koyi, J. O. H. Swantesson, and C. J. Talbot, "Effect of basal friction on surface and volumetric strain in models of convergent settings measured by laser scanner," Journal of Structural Geology, vol. 30, no. 3, pp. 366-379, 2008.

[27] N. Cubas, B. Maillot, and C. Barnes, "Statistical analysis of an experimental compressional sand wedge," Journal of Structural Geology, vol. 32, no. 6, pp. 818-831, 2010.
[28] P. Souloumiac, B. Maillot, and Y. M. Leroy, "Bias due to side wall friction in sand box experiments," Journal of Structural Geology, vol. 35, pp. 90-101, 2012.

[29] G. Corti and T. P. Dooley, "Lithospheric-scale centrifuge models of pull-apart basins," Tectonophysics, vol. 664, pp. 154-163, 2015.

[30] L. Godin, C. Yakymchuk, and L. B. Harris, "Himalayan hinterland-verging superstructure folds related to forelanddirected infrastructure ductile flow: insights from centrifuge analogue modelling," Journal of Structural Geology, vol. 33, no. 3, pp. 329-342, 2011.

[31] J. Adam, J. L. Urai, B. Wieneke et al., "Shear localisation and strain distribution during tectonic faulting-new insights from granular-flow experiments and high-resolution optical image correlation techniques," Journal of Structural Geology, vol. 27, no. 2, pp. 283-301, 2005.

[32] S. Marshak, S. S. B. Haq, and P. Sen, "Ramp initiation in foldthrust belts: insight from PIV analysis of sandbox models," Journal of Structural Geology, vol. 118, pp. 308-323, 2019.

[33] J. Fedorik, F. Zwaan, G. Schreurs, G. Toscani, L. Bonini, and S. Seno, "The interaction between strike-slip dominated fault zones and thrust belt structures: insights from $4 \mathrm{D}$ analogue models," Journal of Structural Geology, vol. 122, pp. 89-105, 2019.

[34] J. Mugnier, P. Baby, B. Colletta, P. Vinour, P. Bale, and P. Leturmy, "Thrust geometry controlled by erosion and sedimentation: a view from analogue models," Geology, vol. 25, no. 5, pp. 427-430, 1997.

[35] M. Panien, G. Schreurs, and A. Pfiffner, "Sandbox experiments on basin inversion: testing the influence of basin orientation and basin fill," Journal of Structural Geology, vol. 27, no. 3, pp. 433-445, 2005.

[36] B. Colletta, J. Letouzey, R. Pinedo, J. F. Ballard, and P. Balé, "Computerized X-ray tomography analysis of sandbox models: examples of thin-skinned thrust systems," Geology, vol. 19, no. 11, pp. 1063-1067, 1991.

[37] L. Mattioni, L. Le Pourhiet, and I. Moretti, "Rifting through a heterogeneous crust: insights from analogue models and application to the Gulf of Corinth," Geological Society, London, Special Publications, vol. 253, no. 1, pp. 213-231, 2006.

[38] S. Ellis, G. Schreurs, and M. Panien, "Comparisons between analogue and numerical models of thrust wedge development," Journal of Structural Geology, vol. 26, no. 9, pp. 16591675, 2004.

[39] M. Panien, G. Schreurs, and A. Pfiffner, "Mechanical behaviour of granular materials used in analogue modelling: insights from grain characterisation, ring-shear tests and analogue experiments," Journal of Structural Geology, vol. 28, pp. 1710-1724, 2006.

[40] C. Bonnet, J. Malavieille, and J. Mosar, "Interactions between tectonics, erosion, and sedimentation during the recent evolution of the Alpine orogen: analogue modeling insights," Tectonics, vol. 26, no. 6, 2007.

[41] M. Warsitzka, J. Kley, and N. Kukowski, "Salt diapirism driven by differential loading - some insights from analogue modelling," Tectonophysics, vol. 591, pp. 83-97, 2013.

[42] Z. Wu, H. Yin, X. Wang et al., "The structural styles and formation mechanism of salt structures in the Southern Precaspian Basin: insights from seismic data and analog modeling," Marine and Petroleum Geology, vol. 62, pp. 58-76, 2015. 
[43] J. Adam, M. Klinkmüller, G. Schreurs, and B. Wieneke, "Quantitative 3D strain analysis in analogue experiments simulating tectonic deformation: integration of X-ray computed tomography and digital volume correlation techniques," Journal of Structural Geology, vol. 55, pp. 127-149, 2013.

[44] Q. Fisher and R. Knipe, "The permeability of faults within siliciclastic petroleum reservoirs of the North Sea and Norwegian Continental Shelf," Marine and Petroleum Geology, vol. 18, no. 10, pp. 1063-1081, 2001.

[45] E. Hooper, "Fluid migration along growth faults in compacting sediments," Journal of Petroleum Geology, vol. 14, pp. 161-180, 1991.

[46] R. J. Knipe, G. Jones, and Q. J. Fisher, "Faulting, fault sealing and fluid flow in hydrocarbon reservoirs: an introduction," Geological Society, London, Special Publications, vol. 147, no. 1, pp. vii-xxi, 1998.

[47] J. R. Boles, P. Eichhubl, G. Garven, and J. Chen, "Evolution of a hydrocarbon migration pathway along basin-bounding faults: evidence from fault cement," AAPG Bulletin, vol. 88, no. 7, pp. 947-970, 2004.

[48] Z. Jin, J. Cao, W. Hu et al., "Episodic petroleum fluid migration in fault zones of the northwestern Junggar Basin (Northwest China): evidence from hydrocarbon-bearing zoned calcite cement," AAPG Bulletin, vol. 92, no. 9, pp. 1225-1243, 2008.

[49] I. Moretti, "The role of faults in hydrocarbon migration," Petroleum Geoscience, vol. 4, no. 1, pp. 81-94, 1998.

[50] L. Zhang, X. Luo, G. Vasseur et al., "Evaluation of geological factors in characterizing fault connectivity during hydrocarbon migration: application to the Bohai Bay Basin," Marine and Petroleum Geology, vol. 28, no. 9, pp. 1634-1647, 2011.

[51] A. P. Allen and R. J. Allen, Basin Analysis: Principles and Applications to Petroleum Play Assessment, 2013.

[52] B. Liu, Y. Gao, K. Liu et al., "Pore structure and adsorption hysteresis of the middle Jurassic Xishanyao shale formation in the southern Junggar Basin, Northwest China," Energy Exploration \& Exploitation, vol. 39, no. 3, pp. 761-778, 2021.

[53] M. Kervyn, M. N. Boone, B. van Wyk de Vries et al., "3D imaging of volcano gravitational deformation by computerized Xray micro-tomography," Geosphere, vol. 6, no. 5, pp. 482498, 2010.

[54] W. Sassi, B. Colletta, P. Balé, and T. Paquereau, "Modelling of structural complexity in sedimentary basins: the role of preexisting faults in thrust tectonics," Tectonophysics, vol. 226, no. 1-4, pp. 97-112, 1993.

[55] K. Ueta, K. Tani, and T. Kato, "Computerized X-ray tomography analysis of three-dimensional fault geometries in basement-induced wrench faulting," Engineering Geology, vol. 56 , no. $1-2$, pp. $197-210,2000$. 